\title{
〔フォーラム $5-3]$
}

\section{半導体製造プロセスにおける電磁力の応用:マクロとナノスケールの融合 Application of electromagnetic forces to Semiconductor fabrication}

\author{
柿本浩一（九州大応力研）田代昭正 石井秀夫 篠崎高茂 正 橋本良夫 \\ Koichi KAKIMOTO, Akimasa TASHIRO, Hideo ISHII, Takashige SHINOZAKI and Yoshio HASHIMOTO \\ RIAM, Kyushu University, 6-1, Kasuga-Koen, Kasuga, 816-8580, Fukuoka
}

\begin{abstract}
This paper aims to study mechanism of heat and mass transfer in silicon melt under electromagnetic Czochralski growth (EMCZ). The EMCZ method is a one of the candidate method to reduce density of voids in which a lot of vacancies are agglomerated. The experimental works revealed that heat and mass of oxygen impurity was enhanced in the EMCZ method, while the mechanism of such enhancement is not clarified. The object of the present work is to clarify the enhancement mechanism of heat and mass transfer. Moreover, molecular dynamics simulation was carried out to estimate distribution of defects during growth.
\end{abstract}

Key Words: Silicon, Chochralski, Magnetic fields, oxygen

\section{1.はじめに}

情報化社会を担うシリコン単結晶への要求は、年々厳し くなりさらなる高品質化が求められている。シリコン結晶 の内部には、原子スケール欠陷である原子空孔が凝集して 形成した空洞欠陥が、大きさと密度がそれぞれ約 $100 \mathrm{~nm}$ と $10^{5} \mathrm{~cm}^{-3}$ 程度で存在している。この空洞欠陥を除去する ことが、超高密度の電子デバイスを実現させるためには必 須である。

この空洞欠陥は固液界面付近において原子空孔の凝集 により形成されているために、固液界面近傍の温度が高い 領域での空孔濃度を精密に制御することが、問題解決には 必要である。空孔濃度はほぼ平衡濃度であるために、空孔 丧度そのものは温度によって決定される。したがって、空 洞欠陥の除去には、結晶育成中の結晶内の温度分布、特に 子液界面近傍の温度分布を精密に制御する必要がある。

一般に凝固問題を考える場合、融液の対流と固液界面形 状は強くリンクしているために、固液界面形状を制御する ためには融液の対流を制御する必要がある。

今までにも融液対流の制御に関する報告は多数見られる が、主に強力な静磁場を印加する方法が採用されてきてい る。しかし、この方法のみでは融液対流の変化の領域は限 られており、大きな固液界面形状の変化をもたらすにはい たらなかったのが現状である。これは、従来は主に融液対 流を抑制する方向に対流を制御する方策がとられてきたが、 最近、渡辺ら (1)により静磁場と電流印加の効果を同時に利 用することにより、電磁力による制御された融液対流を実 現することが可能となってきている。これは、従来の融液 対流の抑制により対流を制御しよとするものではなく、意 図的に融液を摬找することにより、従来では達成できなか った固液界面形状を実現することが特徴である。これによ り、空洞欠陥形成の確率を低く抑えることに成功している。

本研究の目的は、数值計算により EMCZ 法の特徽である熱 と不純物の輸送が促進されるメカニズムについて明らかに することである。特に、温度、速場、電場、不純物である 酸素の各分布についての特徵を明らかにし、特に数種類の 電極は位置の場合を考慮に入れ、EMCZ法の特徵を明ら かにする。さらに、分子動力学法を用いて原子レベルの欠 陥の拡散係数を推定し、ナノスケールの欠陷発生抑制の例 を述べる。

\section{2. 数値モデル}

本研究では、有限体積法を用いて 3 次非定常の計算を行 い、E MCZ の条件下にお汸るシリコン融液対流現象の 3
次元構造を明らかにした。図 1 は3 つの異なった E M C Z の配置を示す。ここでは、印加した磁場は一様な垂直磁場 とした。（a）（b）（c）は、それぞれ電極配置が異な り、（a）の場合は電極から電流を注入し融液中を通過し て結晶へながれる。したがって、電極・融液界面と固液界 面では電流密度が異なることとなり、非対称はローレンツ 力の分布が期待できる。（b）の場合は、2 回対称に電極 を配置した構成であり、結晶には電流が流れず 2 本の電極 に逆方向に等量の電流が流れることとなり、この場合も

(a)の場合と同様非対称なローレンツカの分布が期待で きる。（c）は、電極が結晶の周囲に対象に配置され、結 晶中を流れてきた電流は等方的に電流が流れ、対称性のよ いローレンツカの分布が期待できる。

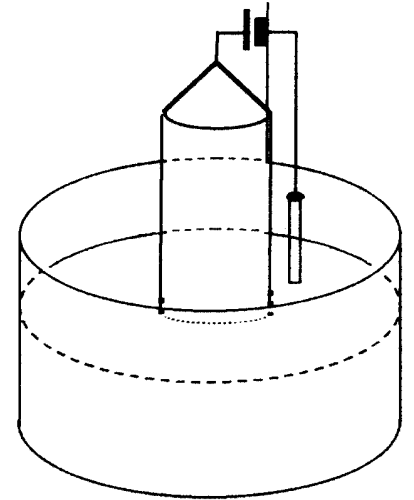

(a)

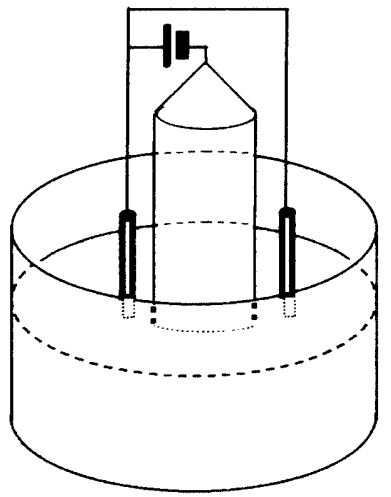

(b)

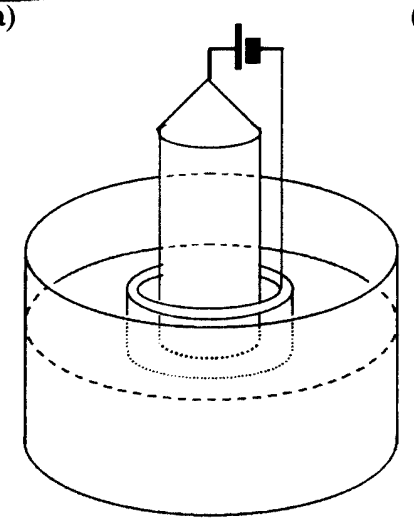

(c)
Fig.1 Schematic diagrams of EMCZ. (a) asymmetric electrode, (b) symmetric electrodes, (c) cylindrical electrode.

〔No.02-2〕日本機械学会第 15 回計算力学講演会講演論文集〔2002-11.2 4 


\section{3. 流動解析結果}

図 2 と図 3 の（a）（b）（c）はそれぞれ融液表面近 傍の速度分布と温度分布を図 1 の（a）（b）（c）の場 合について計算した結果を示す。（a）の場合は、電極近 傍で時計回りの大きな渦が生じていることがわかる。これ は電極近傍に電流密度が大きな領域が形成されるために、 磁場との結合によるローレンツカが大きくなったためであ る。また、電極近傍の渦に加えて、反時計回りの渦も回転 軸が坩堝中央部からずれた位置に形成されていることがわ かる。このために、坩堝から結晶への流れが形成されてい ることがわかる。一方、（b）の場合は 2 つの電極の周囲 に回転方向が異なる渦が形成され手いることがわかる。こ れは電流の流れる方向がお互いに異なるために、ローレン ツ力の方向が逆になったためである。（c）の場合は、電 流が軸対称的流れるためにローレンツカの分布も軸対称と なり、結果として周方向の流れも軸対称流となることがわ かる。

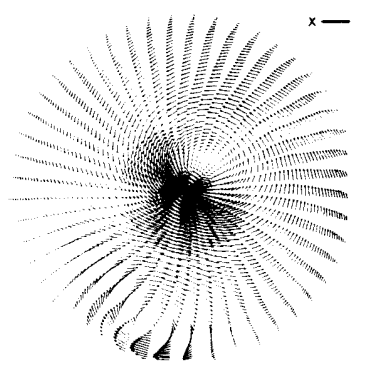

(a)
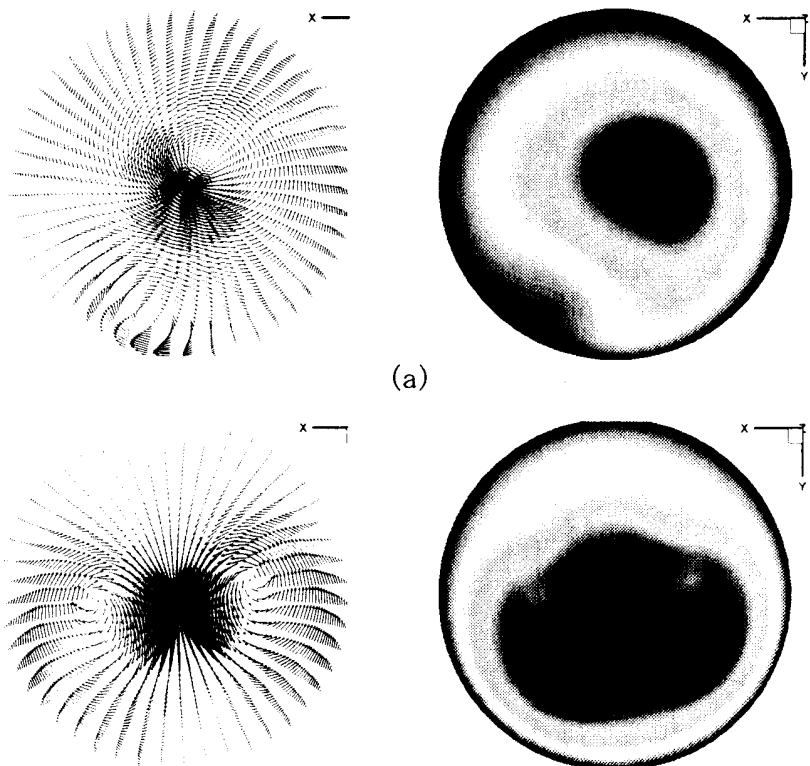

(b)
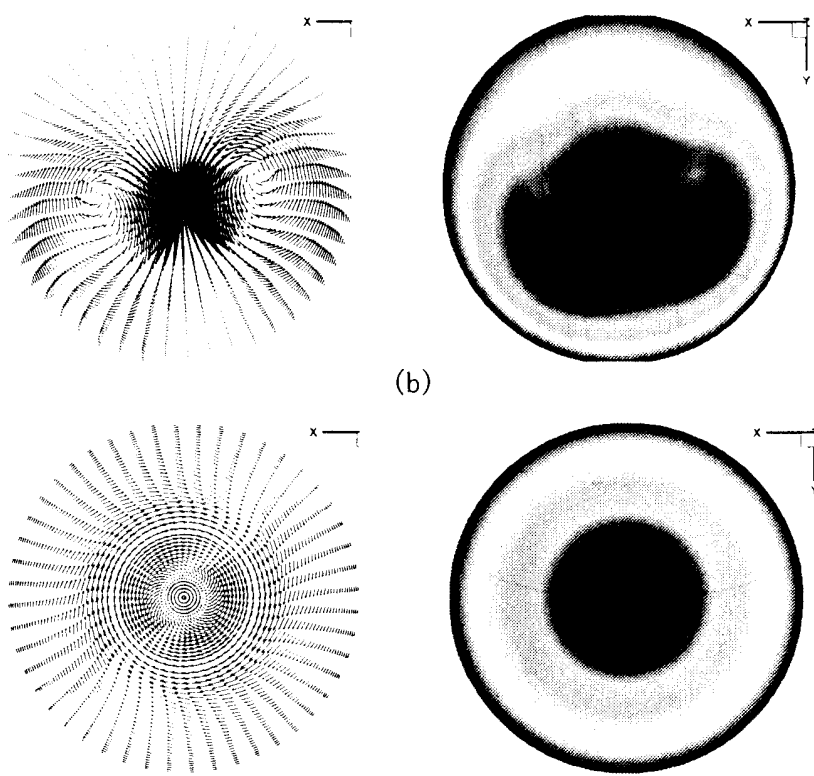

(c)

Fig. 2 Velocity and temperature profiles at the top of the melt of EMCZ. (a) asymmetric electrode, (b) symmetric electrodes, (c) cylindrical electrode.

\section{EMCZの非対称性について}

図 2 に示したように、電極の配置により周方向のながれ が大きく変化することがわかる。(a) と (b) の場合は、電極 が非対称配置であるために周方向に非対称流が発生する。 このために、子午面内の流速の周方向平均は (c)の場合に比 較して大きくなることがわかった。

（a）と（b）の場合のように、周方向の流動に意図的に非対
称性を導入することにより、子午面内の流動の促進が行わ れていることがわかった。(c)の場合は、対称な構造で周方 向の流速が大きくなったために、遠心力により子午面内の 流速が抑制されることとなる。したがって、(a) と (b) の場 合のほうが、(c)の場合に比較してより輸送が抑制され散る ことがわかる。これは図 3 の温度分布からもわかる。EMCZ の熱伝達の本質は、非対称なローレンツカの分布にある。

\section{5. 分子動力学法によるナノスケール欠陷形成解析}

分子動力学法を用いて代表的な半導体であるシリコン 中の欠陥の輸送現象に関する検討を行った。

本研究では、等温等圧アルゴリズムの中で式 $(1 、 2)$ に示すような等方的なスキームであるアンデルセン法と、 異方的スキームであるパリネロ・ラーマン法の両方を用い た。

$m \frac{d^{2} \vec{r}_{i}}{d t^{2}}=-\frac{\partial \Phi}{\partial \vec{r}_{i}}-\frac{1}{3}\left(m \frac{d \vec{r}_{i}}{d t}\right)\left(\frac{1}{V} \frac{d V}{d t}\right)$

$M \frac{d^{2} V}{d t^{2}}=\frac{1}{3 V}\left[\sum_{i=1}^{N} \frac{\vec{p}_{i}^{2}}{m}-\sum_{i=1}^{N} \vec{r}_{i} \cdot \frac{\partial \Phi}{\partial \vec{r}_{i}}\right]-P_{e x}$

ここで、m, $\phi, \mathrm{V}, \mathrm{t}, \mathrm{M}, \mathrm{p}, \mathrm{P}_{\mathrm{ex}}$ はそれぞれ、原子の質量、 ポテンシャルエネルギー、体積、時間、体積変化用ピスト ンの質量、運動量、外部圧力である。

図 3 は、空孔と格子間原子久陷の拡散係数の推定値であ る。この倸数を用いて、空孔と格子間原子欠陥の生成消滅 を含む拡散方程式を解くことにより、半導体中に存在する ナノスケール欠陥の分布を定量的に予想することが可能と なった。
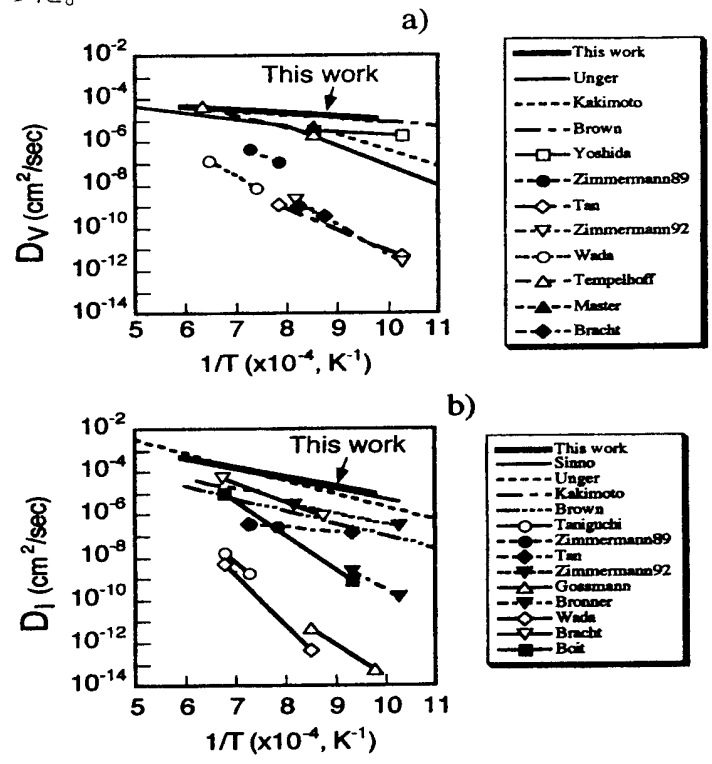

b)

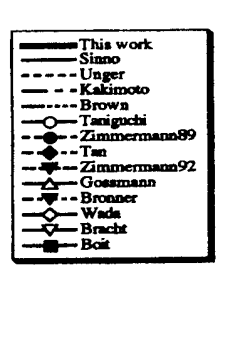

Fig. 3 Calculated diffusion constants of vacancy (a) and interstitial.(b).

\section{5. 結論}

E M C Z 結晶成長における電極の非対称性による熱と物 質の輸送の促進効果を明らかにした。さらに、原子レベル の数值計算を併用し、欠陥形成予測を行った。 参考文献

(1) M. Watanabe et al., Jpn. J. Appl. Phys, 38 (1999), L10. 